\title{
Business networking relationships for business success
}

\author{
S. de Klerk* and J. Kroon \\ School of Business Management, North West University, Potchefstroom Campus, \\ Private Bag X6001, Potchefstroom 2520, Republic of South Africa \\ Saskia.DeKlerk@nwu.ac.za
}

Received March 2008

\begin{abstract}
This study explored the context of business relationships in the networking practices of South African businesses. The objective of this study was to investigate the networking practices of Gauteng businesses and specific perceptions and experiences of business owners and managers on their business networking objectives. A multi-method design was used, which included qualitative research (focus groups) and quantitative research (structured questionnaire). Perceptions recorded amongst the participants indicated that business relationships are built for referrals and strategic networking connections. Different forms of business networking and different motivations behind the building of business networks were identified, such as profit, access to resources and improved efficiency. Different characteristics in terms of business relationships were identified and different age groups, group 1 (44 years and younger) and group 2 (older than 45 years of age) indicated that they felt differently about the number of connections in a network. This article can contribute to the business practice of networking and the awareness of business owners and managers in terms of the importance and influence of networking in their specific business.
\end{abstract}

*To whom all correspondence should be addressed.

\section{Introduction}

Business networks are complex and dynamic, and are characterised by direct and indirect relationships. Human favouritism forms part of a business and therefore human relationships need to be maintained and constantly pursued (Ford, Gadde, Hakansson \& Snehota, 2003: xi). Business networking is a process that requires management with unique applications in different circumstances. Advantages of this include a wide and balanced relationship network basis, repeated transactions, results beyond the abilities of the single business, job creation and access to information and opportunities (Baker, 2000).

Networking enhances management processes and relationships and provides a competitive advantage (Tullier, 2004:28). The number of contributions is measured by means of the time saved, the additional revenue received and the estimation of the value of networking (De Man, 2004:2). Networks can occur within a business or between businesses and combinations of these networks may differ in terms of the flow and/or sharing of products, services or resources and the relationships between the businesses (Grandori, 1999:92).

Business networking therefore embodies the relationships between different businesses and the utilisation of these relationships to create and support a competitive advantage in business (Wickham, 2004:324). Businesses are empowered through their relationship networks in that societies can be shaped, and the economies of countries can even be affected by these relationship connections through enhancing living standards and economic growth (Beck,
2000:2). Networks put a business in the position to gain access to larger global markets, to benefit from economies of scale and to compete with the best large businesses across the world (Lipnack \& Stamps, 1993:5).

Even though there are many different networks, for instance information and technology networks, e-commerce, career and social networks, this study takes its vantage point from a business networking perspective. The definition of networking upon which this study is based relies on business relationships and approaches the network as a net or web of relationships that are interwoven, and the collective results of networking are greater than individual connections would have been. Researching the single components might lead to an oversimplification of the concept and therefore a holistic approach seems to be more appropriate.

The objective of this study was to investigate the advantages of networking for businesses in that the combined effort leads to results beyond the abilities of the single business, jobs can be created and local economies can experience growth (Lipnack \& Stamps, 1993:5). Business opportunities can be co-created (Giovagnoli \& CarterMiller, 2000:151), knowledge and relational support can be communicated and exchanged to add value and link the different role players successfully (Breiger, Carley \& Pattison, 2003:368).

The problem statement of this paper entails that the ability of the businesses to network within the economy is of great importance in determining business opportunities in the market and to contribute to the establishment or maintaining and overall sustaining of a competitive advantage. Simply 
put, what is the current state of networking practice amongst South African businesses?

\section{Internal and external business networking}

Global business network operations in essence utilise four networks, namely (1) internal relations and networks that are connected to the (2) dynamic networks of external businesses through (3) parallel and flexible linkages with a shared set of collective outcomes and supported by a (4) cost-efficient information technology infrastructure network (Desanctis \& Fulk, 1999:71-72). Businesses engage in networking relationships on different levels, for instance on industry level, on a group level and then within the business on their own level of connections (De Man, 2004:118-129).

Business networking systems involve the tendency of businesses to move closer to its partners through mergers or by forming new alliances. By changing their own or a partner's position in the network, risks may be hedged and competitors may be disrupted, or constricted (De Man, 2004:118).

On the strategic business network level, the business might decide to approach its partner's partner to gain a competitive advantage, build a bridge in a network or fill open positions. Furthermore, weak ties can be strengthened, sub-networks can be created and the membership mix can be changed for a better distribution amongst competencies (De Man, 2004:123).

Different relationships exist between businesses and this range from arm's length relationships with lower levels of trust and commitment, to strategic alliances and partnerships with higher levels of trust and commitment (Moberg \& Speh, 2003:2).

Subcontracting contributes to increased flexibility of a business' production function. The strategic networked business uses externalised production and outsourcing or subcontracting of proportions of different production phases or levels of development (Chell, 2001:38). One of the most important disadvantages of choosing the wrong partner in outsourcing is the possible loss of control, which could occur due to the lack of clear boundaries when the activities become highly diversified (Ford, 1998:127).

With an in-sourcing business structure, the business attempts to satisfy its own needs in terms of producing what it needs. Skeleton staff is assigned to the different functions and most divisions will perform multiple tasks internally and perform multiple roles (Hitt, Ireland, Camp \& Sexton, 2002:9,106-123,255). Internalising business operations is most likely to occur in highly competitive industries where information is highly classified and partnerships might take away a business's competitive advantage (Bridgewater \& Egan, 2002:127).

A virtual organisation which is developed for new segments and which aims to include new cooperation partners will typically involve distinguishing between the different approaches of the subcontracting (Chell, 2001:41). According to the capitalist approach, businesses depend largely on networks, especially small businesses that depend strongly on the relationships that are part of their own individual and independent network (Chell, 2001:42). Networked businesses form a boundary-less network of interconnected value activities managed with relational trust (Desanctis \& Fulk, 1999:24).

Political exchange relationships are a crucial business agreement and a business needs to adapt business-exchange relationships in strong political environments to find a mutually beneficial interdependency. This might take place by direct or indirect means with a view to gain influence and stature. The different scenarios of political exchange relationships and elements that a business should try to change into influential factors are summarised in Table 1.

\section{Table 1: Political exchange relationship activities}

\begin{tabular}{l|l}
\hline Adaptation & Influence \\
\hline Mutual interdependency. & $\begin{array}{l}\text { Dependence on the political role- } \\
\text { players. }\end{array}$ \\
\hline $\begin{array}{l}\text { Mutual interaction and } \\
\text { benefit. }\end{array}$ & $\begin{array}{l}\text { Supremacy of the political role- } \\
\text { players. }\end{array}$ \\
\hline Cooperation. & Conflict. \\
\hline Trust. & Mistrust. \\
\hline Negotiation and convincing. & One-sided decisions. \\
\hline \multicolumn{2}{l}{ Source: Hadjikhani \& Thilenius (2005:30) }
\end{tabular}

\section{Strategic business networking}

Strategic business networking is a crucial, dynamic and evolving part of a business (Boe \& Youngs, 1989:1). Business relationships basically consist of a 1: $\mathrm{n}$ ratio (one to many) relationships. It describes a relationship in which one business sets the rules and standards and the other has to accept or decline the offer (Österle, Fleisch \& Alt, 2001:22). Business networking is described as the process whereby time and money are invested in building, adapting, developing, relating, combining and understanding the contributions of different role-players (Holmen, Pedersen \& Torvatn, 2005:1244).

Strategic business networks can include the links between the business and its customers, suppliers, bankers, regulations authorities, family and accountants, amongst others (Jones \& Tilley, 2003:26). Networks need to be managed as an organisational structure. This networking structure has definite distinguishing factors, as is the case for other organisational structures such as the cooperation and strategic alliance (Bridgewater \& Egan, 2002:10). The success of networking lies in the way in which the different levels of relationships webs are managed (Bridgewater \& Egan, 2002:10).

Business is conducted by people with people they favour and know (Boe, 1994:83). A network needs to be treated in the same way as one would treat any other business aspect and management needs to be developed and improved constantly (Boe, 1994:149). Each business will have its own unique application of networking because of its own relationship mixture (Bridgewater \& Egan, 2002:33). The strategic beneficial elements may be tangible or intangible 
and may include physical, financial, intellectual, technical and other human resources (Ford et al., 2003:18).

A strategically chosen alliance refers to an instance where the relevant businesses enter into an agreement where they share power, resources, expertise, knowledge or technology to create a mutually beneficial situation (Muthusamy \& White, 2006). The needs of all the involved parties must be met (Thompson \& Martin, 2005:580). This form of business is not only found between businesses in the same field or industry, but also among businesses across industries that form strategically chosen divergent operations along value chains (Desanctis \& Fulk, 1999:23). Geographically businesses may also tend to group together in a sort of consortium or Japanese 'keiretsu' (family of businesses) where the involved businesses share and support one another where possible (Thompson \& Martin, 2005:583).

Strategic business network choices evolve around customer portfolios and the benefits are expected to be derived from the portfolios and the organisation of the business in order to achieve maximum effectiveness and efficiency (Ford, 1998:83). It is often formed as part of a strategy to achieve global competitiveness (Muthusamy \& White, 2006). Therefore, knowledge embeddedness leads to synergy and more successful alliances (Nielsen, 2005:1195).

Alliances can also be an organisational option where businesses share risks, profit, control, processes and mutual dependency, for instance when entering foreign markets or introducing innovation (Ernst \& Bamford, 2005:133). Sometimes being part of a stable and comfortable arrangement or alliance may lead to a position where new opportunities can be missed, and changing the arrangement or alliance may be much more complicated than to establish a new alliance or pursuing the opportunity by oneself (Ernst \& Bamford, 2005:134).

There are different reasons for the development of different strategic alliances. International strategic alliances are aimed at overcoming cultural and linguistic barriers, international tariffs, political risks, transportation costs, expropriation or to form alliances that assist in forming a stronger competitive position (Muthusamy \& White, 2006) for the business as a whole (Thompson, Gamble \& Strickland,
2006:134). Businesses may also choose to be part of a variety of alliances and therefore tap into a variety of different resources at once (Thompson \& Martin, 2005:584) and meet different objectives at once (Thompson \& Martin, 2005:589).

Different industries can also join in a strategic alliance where the aim is to create, but also enhance the competitiveness of the role-players in that specific situation. Different positions are therefore available, for instance strategic alliances between non-competing businesses, and between competing businesses. A balance of power, a clear indication of the boundaries of each role-player and a clearly agreed level of quality can be regarded as some of the prerequisites for establishing a successful alliance (McGee, Thomas \& Wilson, 2005:395-398).

\section{Strategic issues in business relationship networks}

Templeton (2003:83) describes the system of networking as consisting of five elements resembling five strategic issues that influence the business network of De Man (2004:57). When building a network, the focus should be on a network that supports one's own personal and professional needs and goals (Boe, 1994:153). Table 2 illustrates the conceptualisations of networking.

The focus of a specific strategic network should not only be on establishing and maintaining strong relationships; weak or loose relationships are also important to the business (Gruszczynski, 2005). Each relationship contributes large or small amounts of social capital to the relationship in terms of money, goods or services or knowledge of these specific elements (Garton, Haythornthwaite \& Wellman, 1997). Stronger relationships are more likely, however, to share resources, but weak connections share accessibility to more diverse types of resources (Garton et al., 1997). Another description of network strength is to investigate the strength of the embeddedness or the strength of the connections between the different role-players in the network (Hadjikhani \& Thilenius, 2005:32).

Table 2: Strategic issues of business relationship networking

\begin{tabular}{l|l}
\hline De Man (2004:57) & Templeton (2003:83) \\
\hline The strength of the established alliance & $\begin{array}{l}\text { Realising the power of a network in terms of 250 clients in actual fact gives you access to 250 } \\
\text { by } 250 .\end{array}$ \\
\hline The size of the network & Use your personal sphere of influence to which you have access, including friends and family. \\
\hline Number of partners & $\begin{array}{l}\text { ABC your clients in terms of A (most important contacts), B (individuals that promote and } \\
\text { understand, therefore support your cause) and C (unsure about their level of interest, but work } \\
\text { on building a better relationship). }\end{array}$ \\
\hline Diversity of partners - mix & $\begin{array}{l}\text { Educate your staff on handling and appreciating differences. } \\
\text { peveloping alliances between different } \\
\text { partners - clustering }\end{array}$ \\
\hline
\end{tabular}


Relationships provide parameters for business activities, they allow management to change ideas and involve thinking and acting by multiple partners to add to the value of decisions and business activities (Ford, 1998:59). Exploration or exploitation of a network entails the optimal utilisation of role-players in terms of productivity, efficiency, reducing costs, and improving existing resources such as information, technology, skill and expertise (Nielsen, 2005:1200).

In the networked structure, highly specialised and competent individuals are linked through computers and other intelligent devices so that each can contribute their specialised tasks towards the successful completion of the large complex assignment (Larsson \& Lundberg, 1998:86$87)$. Innovation is cultivated and people tend to be more successful when they have a diverse network with people who drive towards progress (Petrusewicz, 2003). The challenge lies in combining the different strengths of various role-players to create a favourable mix in the network (Singer, 2004:21). Strategic business networking opportunities can be based on healthy referrals that are made possible by the creation of relationships with business professionals that offer other services to one's customers and, once this process is established, it could create win-win relationships that may lead to cross-referrals for future business (Ball, 2005:36).

Businesses invest a considerable number of resources in the establishment, management and governance of these strategic partnering relationships. Therefore, they need to have closure on factors such as the extent of the loss of control, the uncertainty of future outcomes, the extent of each partner's demand of resources or the costs involved in deriving the desired benefits, the preclusion of each partner's boundaries and possessions, and the extent of confidentiality in terms of the exposure to one's partner's partners (Gemünden, Ritter, \& Walter, 1997:92).

Strategically coordinating relationships reduce transaction costs and provides the necessary support for the transfer of commercial intelligence and task-specific knowledge. These strategic relationships facilitate inter-business learning and the creation of internal knowledge, adapt technologies to the changes in the business and enable the participants in the relationship network to learn from the feedback received (Boyce, 2001:12). Cooperation clusters offer support and cooperation in production, marketing, distribution and technological development. The critical mass and combinations of diverse skills may lead to competitive advantages for the businesses involved (Gruszczynski, 2005:3).

The business's relationship position in the network holds certain advantages; the relationships can open opportunities to other settings in which alternative experience can be gained (Ford, 1998:59). The position of the role-player will determine his or her importance and this will be determined by the number of connections and the distance between the different connections (Morville, 2002). Therefore, to determine a business's position is to determine its portfolio of relationships, links, resources and specific relationships that made business happen (Ford, 1998:49; Ford et al.,
2003:7). Businesses in the network will strive to establish a position of maximum influence in their networks and aspire towards the one that offers the greatest opportunities (Österle et al., 2001:21).

\section{Research design}

The research design consisted of a multi-method approach which included a combination of qualitative (explorative) and quantitative (descriptive) methods (De Vos, 2005:357). The qualitative research consisted of phenomenological research or an interpretive approach. Networking is multidimensional, and in order to gain access to the interweave relationships; a purposive sample was used to access the right people and to gain access to this interwoven range of friendships and connections.

\section{Participants}

After the first focus group a snowball sample was used to conduct a further four focus group discussions comprising of 41 business owners and managers from Gauteng, South Africa, and which were conducted from November 2005 to May 2006. Saturation of results was reached after three focus groups. A further two focus groups were held in an attempt to try to include more middle managers and more participants from the manufacturing sector. The participants are all representative of the business services $(79,40 \%)$, manufacturing $(8,82 \%)$ and retail businesses $(11,76 \%)$ in the Gauteng area. The research was restricted to these three sectors, because of time and financial constraints and the common understanding that these sectors all rely on effective networking practices for business success. The focus group discussions provided rich and deep information leading to a deeper understanding of the phenomena and also guided the wording of the questionnaire.

Gauteng is regarded as the digital cluster of related businesses (Hunter, 2004) and has the highest economic contribution to the Gross Domestic Product with 38\% of economic activity in 2002 happening in Gauteng (South African Government Information, 2003). A networking expert was purposively identified and contacted, and he was then asked to invite between 8 and 12 other business owners and managers in his own network.

The networking experience is related to the amount of networking exposure that a person has had in his or her life. The characteristics of the participants are summarised in Table 3.

\section{Data-gathering and analysis}

The focus group discussions were audio and video taped (visual) and afterwards transcribed and interpreted. The focus group results were analysed by making use of an open coding analysis and by identifying the main themes in terms of the perceptions and the main experiences of the participants. The results were verified by means of an independent transcriber and by member checking. 
Table 3: Participant characteristics

\begin{tabular}{|c|c|c|}
\hline Characteristics & & Participants (\%) \\
\hline \multirow{5}{*}{ Age } & & 100 \\
\hline & $>55$ years & 20 \\
\hline & $45-54$ years & 45,71 \\
\hline & $35-44$ years & 20 \\
\hline & $<34$ years & 14,29 \\
\hline \multirow[t]{5}{*}{ Education } & & 100 \\
\hline & Grade 12 & 9,38 \\
\hline & Diploma or Certificate & 6,25 \\
\hline & Formal education: B-degree & 28,13 \\
\hline & Postgraduate qualification & 56,25 \\
\hline \multirow[t]{5}{*}{ Experience } & & 100 \\
\hline & $1-5$ years & 46,88 \\
\hline & $6-15$ years & 21,88 \\
\hline & $16-20$ years & 21,88 \\
\hline & More than 21 years & 20 \\
\hline \multirow[t]{7}{*}{ Annual turnover } & & 100 \\
\hline & Less than R 5 million & 34,38 \\
\hline & R 5 million to less than R 10 million & 15,63 \\
\hline & R 10 million to less than R 20 million & 15,63 \\
\hline & R 20 million to less than R 50 million & 6,25 \\
\hline & R 50 million to less than R 100 million & 6,25 \\
\hline & More than R 100 million & 21,88 \\
\hline \multirow[t]{10}{*}{ Primary industry } & & 100 \\
\hline & Mining and Quarrying & 3,23 \\
\hline & Manufacturing & 9,68 \\
\hline & Construction & 3,23 \\
\hline & Wholesale and Retail Trade (Including Motor Trade) & 9,68 \\
\hline & Transport, Storage and Communications & 6,45 \\
\hline & Financial, Insurance, Real estate and Business services & 29,03 \\
\hline & Community, Social and Personal services & 6,45 \\
\hline & Private households & 3,23 \\
\hline & Other: & 29,03 \\
\hline
\end{tabular}

The structured questionnaire resulted in a response of 35 . The questionnaire provided information on the individual experience and was used to verify the focus group results. In this study, purposive and snowball samples were used; random samples were not used at any stage. In light of this, the procedure did not include the use of inferential statistics (in other words p-values), but effect sizes. Effect sizes were then used to indicate the differences between the means of the different groups by making use of Cohen's effect sizes (in other words d-values).

The calculation of the effect sizes is applicable to studies where the entire population or a census is made of a population. In this study it was difficult to target the entire Gauteng business population, and therefore the purposive sample forms a sub-population of the entire Gauteng business population. In this the results were interpreted by making use of the guidelines for effect sizes as calculated by:

$d=\frac{\left|\bar{x}_{1}-\bar{x}_{2}\right|}{S}$

(Ellis \& Steyn, 2003:52).

The effect size of the difference between current and ideal findings was then used to determine the practical significance of the differences. In the further analysis of the questionnaire findings the effect sizes were calculated by the statistical program SAS (SAS Institute Inc, 2005).

The between-method triangulation of internal validity was used in this study to verify the results and to reach consensus between the researcher's findings and participants' findings. The results of the one method were also confirmed or validated by using another method (Holloway \& Wheeler, 2002:17).

\section{Results}

During the survey, respondents had a choice of 21 alternatives as motivation for their networking activities. Table 4 provides an overview of the responses.

This survey identified the most important reasons for networking as follows: a method whereby new business can be accessed $(97,14 \%)$ and information on new opportunities and/or additional strategic alliances in specific markets can be obtained $(88,57 \%)$. In addition, networking is utilised to share experiences and exchange ideas $(85,71 \%)$, to obtain access to new or additional marketing channels $(85,71 \%)$ and to find and develop alliances, associates and opportunities for collaboration $(82,86 \%)$. 
Table 4: The main motivation behind networking

\begin{tabular}{|c|c|c|}
\hline Motivation behind networking & Yes (\%) & No (\%) \\
\hline Bringing in new business & 97,14 & 5,86 \\
\hline Forming strategic alliances & 88,57 & 11,43 \\
\hline Obtaining knowledge on new opportunities and markets & 88,57 & 11,43 \\
\hline Sharing experiences and exchanging ideas & 85,71 & 14,29 \\
\hline Obtaining access to new or additional marketing channels & 85,71 & 14,29 \\
\hline Finding and developing alliances, associates and opportunities for collaboration & 82,86 & 17,14 \\
\hline Communicating with potential interest groups & 80 & 20 \\
\hline Obtaining access to new or additional distribution channels & 74,29 & 25,71 \\
\hline Obtaining access to new or additional technology & 74,29 & 25,71 \\
\hline The project is too big or complex to do alone & 74,29 & 25,71 \\
\hline Obtaining knowledge on new business processes & 71,43 & 28,57 \\
\hline Acquiring capital or additional financial resources & 65,71 & 34,29 \\
\hline Career growth & 62,86 & 37,14 \\
\hline To include partners with specific resources and requirements as needed in a relationship & 62,86 & 37,14 \\
\hline Making processes more efficient & 60,00 & 40,00 \\
\hline Launching a new product & 57,14 & 42,86 \\
\hline Obtaining access to specialised skilled labour & 57,14 & 42,86 \\
\hline Acquiring additional productive assets & 54,29 & 45,71 \\
\hline Gaining access to a specific set of coordination outputs through a partner & 54,29 & 45,71 \\
\hline Establishing a brand name & 54,29 & 45,71 \\
\hline Gaining access to political connections & 54,29 & 45,71 \\
\hline
\end{tabular}

\section{Perceptions of business relationships}

Different main themes were identified in terms of the participants' perceptions regarding business relationships and networking. Table 5 provides the detail of the identified main and sub-themes with direct wording or quotes that support each of these findings.

Participants implied that strategic business networks are divided into internal and external networks. No distinction was made between the two forms in some discussions while a clear distinction was made in other discussions. The motivation behind strategic networking recorded during the focus group discussions is that a business can lose business if it does not make use of networking. The motivations behind strategic networking as recorded in this study are summarised in Table 6; and include access to opportunity, improved effectiveness (which generate profit - either in monetary terms or by other means).

There are different opinions regarding who should be consciously included - based on their contribution in terms of money, resources, knowledge or access to knowledge, support and efficiency. Participants were also asked to provide reasons for their conscious networking efforts. Most of the participants replied that they consciously drive their efforts towards successful networking to gain access to opportunities $(94,29 \%)$, as well as to get business support $(91,43 \%)$.

The strategic business relationships that are available in a specific industry or field can prompt businesses to use different business scenarios than those initially planned. In Table 7, the different business relationship scenarios according to the respondents are indicated.

The strategic business scenario preferred by the majority of participants $(80 \%)$ is that the motivation for their business to engage in networking activity is directly linked to personal benefit or higher profits. The most important element is that they will not drive this process if it will have a negative effect their existing networking relationships. A large percentage of participants $(65,71 \%)$ feel that their existing networking relationships are irreplaceable and therefore important to maintain.

Relationships seem to be valued very high by a large percentage $(62,86 \%)$ of respondents while the remaining $37,14 \%$ reported that they value relationships highly in their business.

Characteristics that were recorded as being frequently experienced by respondents include simple ("once-off") exchanges, a large number of exchange relationships, the fact that few role-players engage and the fact that these exchanges are characterised by small and simple information exchanges. Characteristics that were highlighted as ideal characteristics in a business relationship include complex resource exchanges with only a few exchanges and high informational value. A medium effect size was recorded between the frequency of the ideal and current presence of business relationships that indicate that a medium relation is characterised by complex resource exchanges $(d=0,65)$ and high adaptation $(d=0,56)$. A large practical significance was indicated for the ideal and current frequency of exchanges that is accompanied by social exchanges $(\mathrm{d}=0,85)$. Throughout the focus group discussions, participants indicated that they value relationships but a large number indicated that they have no way of measuring the effect thereof on business. This question was aimed at determining the extent to which the measurement of the value of relationships is important in the business. Table 8 provides a summary of the findings on the current and ideal extent to which the value of relationships is measured in a business. 
Table 5: Perceptions and supporting quotes

\begin{abstract}
Main theme and literature verification / support
A person can only build up a reference by building a relationship and

by delivering the expected result on a constant basis.

Boe (1994:9) supports this by stating that personal and professional contacts are developed and nurtured to obtain referrals, advice, assistance, share information and to generate a level of energy that you cannot achieve on your own.
\end{abstract}

Direct wording and quotes from the participants

"The people will be happy to use a reference and you say well surely with a lot of work. Also how do you utilise so many different relationships for more business value than ever for happening anyway than just to sit in your office doing the normal." "Your reference with me has zero negative (feelings) associated with the fact that we haven't met or done business in the last 6/8/10 years, it's got, it's gone through a cycle that our paths have gone slightly different."

"A referral for people and it serves to reward that kind of loyalty and the network actually keeps itself up naturally."

\section{"Absolutely, I think it depends on the network, it can be a} meaningful network or maybe we should talk about a network in a business context, there are naturally other networks as well. It is not as if I want to do business with everyone. I know people that do business with everyone."
Strategic networking embodies connections that enable business transactions and the sharing of personal experiences and include social, professional, personal networks, and technical networking (Profnet, 2006). A diverse mixture of members in a network provide access to diversified levels of power, influence and skills and this may lead to more value and respect for each other's unique contribution to enhance the trust in the network (Uzzi \& Dunlap, 2005:3).

\section{Table 6: The motivation behind strategic networking}

\begin{tabular}{l|l}
\hline Reasons & Quotations to support finding \\
\hline Profit & $\begin{array}{l}\text { “... the purpose of networking is to do business, due to relationships. I mean for me in business, you have, it's a } \\
\text { bottom line thing, you just got to network to push that envelope. There's networking to get work and networking } \\
\text { to do the work." }\end{array}$ \\
\hline $\begin{array}{l}\text { Access to resources or } \\
\text { opportunities. }\end{array}$ & $\begin{array}{l}\text { "Networking I think is all (about) getting together, not necessarily with the purpose of finding another order or } \\
\text { finding another job." "Sometimes the only way that you gain access to business is by mining a network. There } \\
\text { are different ways of networking and you definitely get the fly-by-night opportunists that abuse it." }\end{array}$ \\
$\begin{array}{l}\text { More efficient business } \\
\text { is made possible. }\end{array}$ & $\begin{array}{l}\text { "A (network relationship) is a combination of people you know and proving your ability to deliver and I think in } \\
\text { terms of setting up the network when I realise that the important things are that mutual beneficial relationship." }\end{array}$ \\
\hline
\end{tabular}

\section{Table 7: Strategic business relationship scenarios}

\begin{tabular}{l|r|r}
\hline Scenario & Yes (\%) & No (\%) \\
\hline There are no alternative relationships. & 11,43 & 88,57 \\
\hline $\begin{array}{l}\text { Our business may engage in relationships with other role-players if potential for higher profit exists, but } \\
\text { not at the expense of our current relationships. }\end{array}$ & 80 & 20 \\
$\begin{array}{l}\text { Our business may engage in relationships with other role-players if potential for higher profit exists, even } \\
\text { at the expense of our current relationships. }\end{array}$ & 20 & 80 \\
\hline Our current relationships are irreplaceable. & 65,71 & 34,29 \\
\hline
\end{tabular}

\section{Table 8: The extent to which relationship value is measured in business}

\begin{tabular}{|c|c|c|}
\hline Extent to which the value of relationships is measured in business & Mean & $\begin{array}{l}\text { Standard } \\
\text { deviation }\end{array}$ \\
\hline The value of relationships is not measured & 2,40 & 1,28 \\
\hline If a relationship results in a transaction, it is measured & 2,09 & 0,93 \\
\hline If you are introduced to another important connection & 2,15 & 0,94 \\
\hline If you gain access to information & 2,17 & 1,06 \\
\hline If the alliances' relationship ties are strengthened & 2,28 & 0,77 \\
\hline The value is measured by the size of the network (number of participants) & 2,55 & 1,03 \\
\hline The value is measured by the diversity of people involved & 2,53 & 1,13 \\
\hline The value is measured by the success of the collective governance & 2,56 & 0,91 \\
\hline If common interests and partners are clustered, it is of value & 2,88 & 0,89 \\
\hline Your importance in the network is measured in terms of your position & 2,61 & 1,09 \\
\hline A successful business transaction measures the value & 2,38 & 1,13 \\
\hline If you succeed in securing repeat business, it is of value & 2,27 & 1,15 \\
\hline If you succeed in establishing further alliances, it is of value & 2,41 & 1,04 \\
\hline If you gather referrals, the relationship is of value & 2,33 & 1,05 \\
\hline
\end{tabular}


It is evident from Table 7 that the mean value of relationships in a business is not measured at an effect size of $d=2,40$. According to the participants, the following are possible ways in which the value can, however, be measured: The amount of information accessed may indicate the level of value of the relationships $(d=2,17)$; the size of the network in terms of the number of participating members can indicate the value of the network $(d=2,55)$; the diversity of the people involved $(d=2,53)$; by measuring your position (in terms of importance) in the network $(\mathrm{d}=$ $2,61)$.

The differences between the opinions of the different age groups with regard to the characteristics of a strategic business relationship indicated that age is not relevant to this issue. Table 9 illustrates a very small difference in the answers with regard to business relationship characteristics. This illustrates the tendency that all the listed relationship scenarios and proposed characteristics are relevant, irrespective of the age of the person that engages in networking.

A medium effect was recorded in terms of the difference between the answers of the two age groups. The first difference that was recorded was in terms of participants' preference for a small number of role-players in the network. In response to this question, the two age groups indicated different preferences regarding the number of roleplayers involved in the network. This indicates that preferences in terms of a small number of role-players in a network could be related to the age of the participants. In response to the question as to whether participants prefer a large number of role-players in the network, all of them, irrespective of their age, indicated that they do not prefer a large number of role-players in the network $(d=0,02)$. Participants indicated that they do not expect a large amount of complex information exchange to take place in order for them to establish a networking relationship $(d=0,26)$.

Table 9: Different views on strategic relationship characteristics

\begin{tabular}{|c|c|c|c|c|}
\hline Business relationship characteristics & $\begin{array}{c}\text { Number of } \\
\text { participants }\end{array}$ & Mean & SD & $\begin{array}{c}\text { Effect size } \\
\text { (d-value) }\end{array}$ \\
\hline Few role-players engage & & & & $0,53^{*}$ \\
\hline - $\quad$ Group 1 (44 years and younger) & 12 & 2,33 & 0,49 & \\
\hline - $\quad$ Group 2 (45 years and older) & 22 & 2,71 & 0,72 & \\
\hline Economic basis and low social exchange & & & & $0,51 *$ \\
\hline - $\quad$ Group 1 (44 years and younger) & 11 & 2,00 & 0,63 & \\
\hline - $\quad$ Group 2 (45 years and older) & 21 & 2,57 & 1,12 & \\
\hline Small and simple information exchange & & & & $0,64 *$ \\
\hline - $\quad$ Group 1 (44 years and younger) & 11 & 2,09 & 0,83 & \\
\hline - $\quad$ Group 2 (45 years and older) & 21 & 2,63 & 0,74 & \\
\hline
\end{tabular}

Large effect size $(\mathrm{d}=>0,8=$ a practical significance. A medium effect size $(\mathrm{d}=0,5=$ a substantial finding (Cohen, 1988: $222-223)$

\section{Discussion}

The aim of this research was to determine the motivation behind networking activities, as well as the extent to which networking is currently practiced by the participants and, concomitantly, the extent to which they would want to practice it. This article therefore contributes towards the knowledge of business and especially strategic business relationship networking. The participants indicated that businesses that do not apply networking fail to draw from its high strategic advantage and may even lose business opportunities. According to the business owners and managers, they are motivated to engage in networking in order to realise a profit, gain access to information, opportunities, other resources or connections and to improve their own business's efficiency.

Therefore managers that do not network will not be exposed to new opportunities, ideas, solutions to problems and other resources that can be accessed through involvement with other people. Very few businesses can survive in isolation. To this end establishing strategic relationships is important to any business.

Whether business owners or managers consciously apply themselves to networking or whether they regard relationships highly or even very highly in their business environments, a way of measuring the networking performance in a business is crucial. Possible ways in which businesses can measure the effect of networking were identified as: to measure the amount of information that is accessed through the network, measuring the size of the network or the value of the participants, as well as measuring one's own significance in the network.

Business people of all ages need to realise that networking is a process, and even though all the phases in the process are not always equally important or complicated, each is directed at the individual's or business's actions. All these actions are ultimately directed at building a successful networking practice. This effective networking practice will include those managers who are competent to attract the right balance of connections, skills, ability, knowledge and opportunity. These interweaved relationships will also be included on different levels. Interestingly, the participants older than 45 years of age indicated that they prefer smaller groups in their networks.

\section{Limitations}

It is impossible to cover all the aspects of this issue in one single study. Therefore the study was limited to the following objectives: to provide insight into the business component of networking; to discuss and motivate the 
multi-method research approach to determine networking practices, to investigate the perceptions of Gauteng business owners and managers of networking practices and to support and validate the qualitative research by means of quantitative research.

\section{Recommendations}

Strategic business relationship networking is set to become more competitive in an ever-changing environment. Managers can develop strategic relationships and they should attempt to measure the value of networking in their business transactions. The value of networking should be measured actively in business processes. This can be achieved either by the return on investment in terms of the transactions realised, or by looking at other resources that could be accessed through the strategic relationships, for instance more profit, technologies, skilled workers, opportunities in the market or any other competitive advantage and a multiplying effect into other spheres of life.

Strategic managers should be informed about the importance of relationships in business (De Klerk, 2006:184-186). A strategic manager should therefore prepare clear motivations for each activity in which one engages. These networking motivators should also then be communicated throughout the business - internally, and to all role-players concerned. The value of this article is lodged in the fact that this information can make management aware and assist them in developing or enhancing networking as a strategic business component, and therefore a strategic competitive advantage. Businesses have to position themselves to play a diverse and contributing role in the development of communities in terms of withdrawing material capital sources and employment from the communities.

Future research might include the investigation and analysis of different networks and amongst different role-players and the challenges that are faced in South Africa, including, high levels of diversity; and this can only be bridged by developing and establishing common relationship goals and rules. Common ethical values amongst an equal society may lead to interdependence and successful networking. One group of people should not be superior over another and trust should be earned amongst each other. This notion illustrates one of the networking elements, namely reciprocity.

\section{References}

Baker, W.E. 2000. Networking smart. How to build relationships for personal and organisational success. Lincoln, USA: iUniverse.com.

Ball, L. 2005. 'Networking is the buzzword for referrals', Air Conditioning, Heating \& Refrigeration News 225(2): 36.

Beck, U. 2000. What is globalization? Oxford, U.K.: Blackwell

Boe, A. 1994. Networking success: How to turn business \& financial relationships into fun \& profit. Deerfield Beach, FL: Health Communications.
Boe, A. \& Youngs, B.B. 1989. Is your "net" working? A complete guide to building contacts and career visibility. New York: John Wiley and Sons.

Boyce, G. 2001. Co-operative structures in global business: communication, transferring knowledge and learning across the corporate frontier. New York: Routledge.

Breiger, R., Carley K. \& Pattison, P. 2003. Dynamic social network modelling and analysis: Workshop summary and papers. (Workshop on Dynamic Social Network Modelling and Analysis 2002: Washington, D.C.) Washington, D.C., U.S.A.: National Academic Press.

Bridgewater, S. \& Egan, C. 2002. International marketing relationships: Profitable marketing relationships series. New York: Palgrave.

Castells, M. 1989. The informational city - information technology, economic restructuring and the urban-regional process. Oxford: Blackwell.

Chell, E. 2001. Entrepreneurship: Globalisation, innovation and development. Cornwall: TJ International.

Cohen, J. 1988. Statistical power analysis for behavioural sciences. $2^{\text {nd }}$ Edition. Hillsdale, NJ: Erlbaum.

De Klerk, S. 2006. 'Networking practices amongst Gauteng businesses: An analysis and proposed framework'. Unpublished PhD thesis. Potchefstroom: NWU.

De Man, A. 2004. The networked economy: Strategy, structure and management. Cheltenham, UK: Edgar Elgar.

Desanctis, G. \& Fulk J. (Eds.). 1999. Shaping organisational form: Communication, connection, and community. Newbury Park: California: Sage.

De Vos, A.S. 2005. 'Combined quantitative and qualitative approach'. In De Vos, AS et al. Research at grass roots for the social sciences and human service professions. $3^{\text {rd }}$ Edition. Pretoria: Van Schaik Publishers).

De Vos, A.S., Strydom, H., Fouche, C.B. \& Delport, C.S.L. 2005. Research at grass roots for the social sciences and human service professions. $3^{\text {rd }}$ Edition. Pretoria: Van Schaik Publishers.

Ellis, S.M. \& Steyn, H.S. 2003. 'Practical significance (effect sizes) versus or in combination with statistical significance (p-values)', Management Dynamics, 12(4):5153.

Ernst, D. \& Bamford, J. 2005. 'Your alliances are too stable", Harvard Business Review, 83(6):133-141.

Ford, I.D. 1998. Managing business-relationships. Chichester, UK: John Wiley \& Sons. 
Ford, D., Gadde, L-E., Hakansson, H. \& Snehota, I. 2003. Managing business relationships. $2^{\text {nd }}$ Edition. Chichester, UK: John Wiley \& Sons.

Garton, L., Haythornthwaite, C. \& Wellman, B. 1997. Studying online social networks. [online] http://www.ascusc.org/jcmc/vol3/issue1/garton.html.

Accessed 01 Nov 2004.

Gemünden, H.G., Ritter, T. \& Walter, A. (Eds.). 1997. Relationships and networks in international markets. Oxford, UK: Pergamon.

Giovagnoli, M. \& Carter-Miller, J. 2000. Networking: building relationships and opportunities for success. San Francisco, U.S.A.: Jossey-Bass Wiley Company.

Grandori, A. 1999. Interfirm networks: Organization and industrial competitiveness. London : Routledge.

Gruszczynski, W. 2005. 'Small enterprises' cooperation groups. Importance of personal relationships in small enterprises' cooperation.' Paper delivered at the 4th International Conference of Entrepreneurship - Employment and Beyond, September 8-9, 2005. Sodertörns Högskola University College, Stockholm Sweden.

Hadjikhani, A. \& Thilenius, P. 2005. Non-business actors in a business network: A comparative case on firms' actions in developing and developed countries. Ghauri, Amsterdam: Elsevier.

Hitt, M.A., Ireland, R.D., Camp, S.M. \& Sexton, D.L. 2002. Strategic entrepreneurship - creating a new mindset. Oxford: Blackwell Publishers.

Holloway, I. \& Wheeler, S. 2002. Qualitative research in nursing. $2^{\text {nd }}$ Edition. Oxford, UK: Blackwell Publishers.

Holmen, E., Pedersen A-C. \& Torvatn, T. 2005. 'Building relationships for technological innovation', Journal of Business Research. 58(9):1240-1250.

Hunter, A. 2004. 'South Africa - Gauteng's Innovation Hub opens for business'. Balancing Act News Update African internet developments, 43. [online] http://www.balancingact-africa.com/news/back/balancingact43.html. Accessed 26 April 2005.

Jones, O. \& Tilley, F. (Eds.). 2003. Competitive advantage in SMEs - organising for innovation and change. WestSussex: John-Wiley \& Sons.

Larsson, M. \& Lundberg, D. 1998. The transparent market: Management challenges in the electronic age. London, UK: MacMillan Press Ltd.

Lipnack, J. \& Stamps, J. 1993. The teamnet factor Bringing the power of boundary crossing into the heart of your business. Essex Junction, VT: Oliver Wright Publications.
McGee, J., Thomas, H. \& Wilson, D. 2005. Strategy: Analysis and practice. Berkshire, UK: McGraw-Hill.

Moberg, C.R. \& Speh, T.W. 2003. 'Evaluating the relationship between questionable business practices and the strength of supply chain relationships', Journal of Business Logistics, 24(2):1-19.

Morville, P. 2002. 'Semantic Studios - social network analysis'. [online]

http://www.semanticstudios.com/publications/semantics/000 006.php. Accessed 12 Oct 2004.

Muthusamy, S.K. \& White, M.A. 2006. 'Does power sharing matter? The role of power and influence in alliance performance', Journal of Business Research. [online] http://www.sciencedirect.com/science?_ob. Accessed 5 Apr 2006].

Nielsen, B.B. 2005. 'The role of knowledge embeddedness in the creation of synergies in strategic alliances', Journal of Business Research, 58:1194-1204.

Österle, H., Fleisch, E. \& Alt, R. 2001. Business networking: Shaping collaboration between enterprises. $2^{\text {nd }}$ Edition. Berlin, Germany : Springer.

Petrusewicz, M. 2003. 'Innovators navigate around cliques'. Stanford University. [online] http://www.gsb.stanford.edu/news/bmag/sbsm0305/ideas. Accessed 24 Mar 2005.

Profnet. 2006. 'Profnet, Inc. - Business leads, marketing, networking'. [online] http://www.profnet.org/index.html. Accessed 11 Nov 2006.

SAS Institute Inc. 2005. 'The SAS system for Windows release 9.1 TS level $1 \mathrm{M} 0$ Copyright $\subset$ 2002-2005 by SAS Institute Inc'. Cary, NC : USA.

Singer, B. 2004. The ABC's of building a business team that wins: The invisible code of honor that takes ordinary people and turns them into a championship team. New York: Warner Business Books.

South African Government Information. 2003. Speech by the Deputy Minister of Trade and Industry L Hendricks, at the lunch of the SAWEN Gauteng branch. [online] http://www.info.gov.za/speeches/2003/03100113461006 ht m. Accessed: 26 April 2005.

Templeton, T.L. 2003. The referral of a lifetime: The networking system that produces bottom-line results... every day. San Francisco, CA : Blanchard Family Partnership.

Thompson, A.A., Gamble, J.E. \& Strickland, A.J. 2006. Strategy: Core concepts, analytical tools and readings. $2^{\text {nd }}$ Edition. New York: McGraw-Hill.

Thompson, J. \& Martin, F. 2005. Strategic management: awareness and change. $5^{\text {th }}$ Edition. London: Thompson Learning. 
Tullier, L.M. 2004. Networking for job search and career success. $2^{\text {nd }}$ Edition. Indianapolis, IN: JIST Works.

Uzzi, B. \& Dunlap, S. 2005. 'Managing yourself - how to build your network', Harvard Business Review, 83(12): 5360.

Wickham, P.A. 2004. Strategic entrepreneurship. $3^{\text {rd }}$ Edition. Essex, U.K.: Pearson Education Limited. 